\title{
CINEMAS, NATIONS, MASCULINITIES The Martin Walsh Memorial Lecture (1998)'
}

Résumé : L'étude traditionnelle du cinéma canadien construit l'idée cinématographique de la nation selon une conception de la masculinité hétérosexiste. Cette conception peut étre contesté par la création de canons "queers» basés sur notre histoire, telle que la chronologie d'extraits qu'offre l'auteur. Cependant, cette approche peut aussi marginaliser le cinéma «queer. " Il est peut être plus utile de rendre «queer " les canons contemporains, comme le fait cet article qui voit dans une série de films non-«queers " une expression de la masculinité en crise. Cette article propose aussi de faire une recherche archéologique sur les contributions "queers " cachées : l'étude du travail de Guy Glover, producteur a l'ONF; un examen de «l'homo-sociabilité " comme élément générique crucial; et une analyse des gains réalisés au cours de la période de la révolution sexuelle.

$\mathrm{t}$ is twenty years since Steven Heath gave the first Martin Walsh Memorial Lecture. The topic "Film and Nationhood," was appropriate for a young professional association constituted to represent and promote the new discipline of film studies within a certain national boundary. Thereafter, in the intervening two decades, aspects of national identity and culture have been a recurring theme for Martin Walsh lectures, especially as pertains to our own national cinema, as we used to say. Peter Morris, Gaile McGregor and Peter Harcourt, to mention only three, all offered paradigm-shifting reflections on its canons and contradictions, in 1986, 1989 and 1992 respectively. Hence no one will be surprised that I am tempted to revisit this theme. But a lot of water has passed under the bridge since I heard Heath at Western in 1978, as a novitiate at Concordia with a doctoral thesis still hanging around my neck and my vows still untaken.

Heath paid homage to Martin Walsh's vigorous intellect and rigorous theoretical practice, and invoked his posthumous benediction on the challenge 
he offered us that day. Yet Heath's lecture can't be considered a founding text of the literature on culture and nation either here or elsewhere, for Heath deferred the question, in a way I recall finding patronizing vis-à-vis that small gathering of teachers committed to cultural practice in Canada. Instead he dictated the greater urgency and priority of the theory of apparatus, ideology and the subject, then part of hegemonic Screenspeak, and we Canadians trapped amid Western's pseudo-neo-Gothic architecture assented to his wisdom with the same colonial politeness with which we had welcomed earlier dispatchers of imperial taste, from John Grierson to Tyrone Guthrie. ${ }^{2}$ One of Heath's major prescriptions (which has been cited by Christine Ramsay in her valuable work on the discourses of masculinity and national identity) was about sexual difference:

Any political discussion of cinema and nationhood has to involve discussion of sexual difference but that in no sense, or in a reactionary sense only, can be conceived of as the "addition" of some "further problem": the latter discussion is there in the very terms of the former as point of contradiction and struggle in representation, in the institutions of representing, in the property of images and sounds, in the relations of men and women, their constructions. ${ }^{3}$

Sexual difference would of course become one of the other major recurring interests of Martin Walsh lecturers over the years, from Kaja Silverman to Janet Staiger, especially after our little 1986 membership revolt which effectively instituted, after nine successive male lecturers, the alternation of $\mathrm{XX}$ and $\mathrm{XY}$ chromosomes at the Walsh lectern.

But on that originary day in 1978 I was less interested in the relations of men and women than in those of men and men, and women and women, in putting the sex back in sexual difference. I recall thinking, in response, how contradictory Heath's own embodiment of sexual difference was, how his performance of masculinity seemed to contradict his feminist radicalism: this dour, intimidating enunciator of Screenscripture, reminded me of the High Priest in Murnau's Tabu, or one of the church fathers from Dreyer, at once castrator and phallus, whose shadows banish desire, pleasure and transgression, whose culpabilizing interdictions against narrative and popular culture, against pleasure and diversity, immobilized and cut off. Heath lectured not in the everyday sense of the oral communication of ideas and arguments, nor only in the French sense of a reading - though that it was, unapologetically, a reading - but also in the slangy sense of the lecture as 
admonition, sermon, tonguelashing, as in, "Did he give a lecturing to us would-be nationalists!"

In contrast I found myself conjuring up another brand of masculinity that Martin Walsh himself had embodied-his rippling shoulder length hair and scraggly whiskers, earrings before their time, sparkling eyes, lithe cyclist's body, the lucidity and passion of his writing and political commitment, and the ability to respond, not only to the formal and ideological rigour of Straub/Huillet, but also to their sensuality. For example, in The Bridegroom, the Actress and the Pimp, he had engaged with the freedom and fulfilment of love, and the "ecstatic, shimmering final image of sky and trees. ${ }^{\text {"4 }}$

That summer I came back to Montréal, brushed up my course on Fassbinder, Arzner, Murnau, and a few other inverts I was infiltrating Concordia's Wellesian curriculum with, and pursued the publication of a growing number of pieces on what would now be called queer cinema. This trickle would become a flood but already constituted in my mind not only a irrevocable coming out, academically and professionally, but also a rejection of the rigid and static Mulveyan schema of sexual difference and the political modernist project that Heath personified, a rejection of the divorce of theory and practice. It was also an endeavour to integrate, or so I thought, a culture and politics of sexual identity and class with the transformative political aspirations of Screen, a practice defiantly populist, eclectic and based concretely on both text and audience. Richard Dyer and Robin Wood (the latter was to become the second Walsh lecturer in 1979) had also just bravely published their own pioneering work on sexuality, sexual orientation and cinema, work to which I was immeasurably in debt and which chipped irreparably away at the oedipal edifice of Screentheory. Just as Julia Lesage had already done from a North American feminist viewpoint in Screen's own pages three years earlier, ${ }^{5}$ their work showed how sexist, evasive, elitist, and incomplete the Screen practice was, from the selective import of French theory and unreadable Lacanian exegeses of Ophuls to the unreadable Lacanian exegeses of pornography that were just around the corner at the height of the sex wars-a moment when illegibility was part of the problem, not part of the solution.

These memories then, and this sense of commemorating a moment in 1978 , a sense of the Martin Walsh lecture as a weathervane of the struggles and tides of intellectual fashion within our discipline, of styles of sexual politics and gender performance in the institutions of the cinema and academia, has led me to want to think about Cinemas, Nations, Masculinities. 
I am not the first out queer Walsh lecturer, as I have mentioned, but as the second one looking back on a two-decade list of predecessors, I am overwhelmed by the miraculous inclusiveness of English Canadian liberalism, the procession of straight, white able-bodied Canadian male academics varied not only with seven immigrants (4 Yanks, 2 Brits and a Czech), five foreigners, several Jews and two gay men, but also six women, six filmmakers, and one each of native people, people of colour and French Québécois (the disabled transsexual lesbian is slated for next year). Feeling thus on this occasion something of the burden of representation, and desiring to stay true to that instinct of 1978 to retreat to the text, to the audience, to pleasure, to diversity and to show business, I would like to start with a series of (transcribed) film glimpses, offering what might be called a preliminary queer canon of Canadian cinema, a staging area for my reflections on how a spectrum of meanings of nation and cinema intersects with a spectrum of images of masculinity.

First, two caveats about exclusions. I am not including lesbian-authored or lesbian-themed cinema, though it has been in no small way responsible for the discursive ferment around masculinity in our representations, because there's no time, I am not an expert, and my colleagues Jean Bruce and Chantal Nadeau among others have started that job admirably. ${ }^{6}$ Secondly I am referring exclusively to cinema made in English, since one premise of this research, always open to challenge, is the lingering cultural chasm between our two founding cinemas that has been so often erased at its peril by Ontario film studies.

Here then is a brief runthrough of an alternative queer Canadian canon of voices, visions, and images of alternative male sexuality: 


\section{THE QUEER CANON}

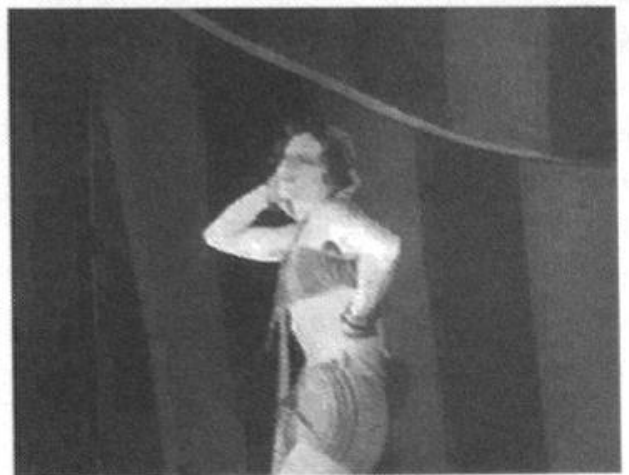

Soldiers All

"Canada Carries On,"

NFB, $1941 .^{7}$

A show mounted by Canadian soldiers stationed in England to entertain their host community.

NARRATOR

And in return for their hospitality, Canada presents "The Sultan's Saturday Night," a dire drama of the Middle East.

A Canadian soldier, dressed provocatively as a harem dancer, enters and gyrates across the stage. The spectators are agog: a 12-year old boy gleams wide-eyed in excitement, a bespectacled middle-aged male is in hysterics, a young man in uniform tweaks his male companion's nose....

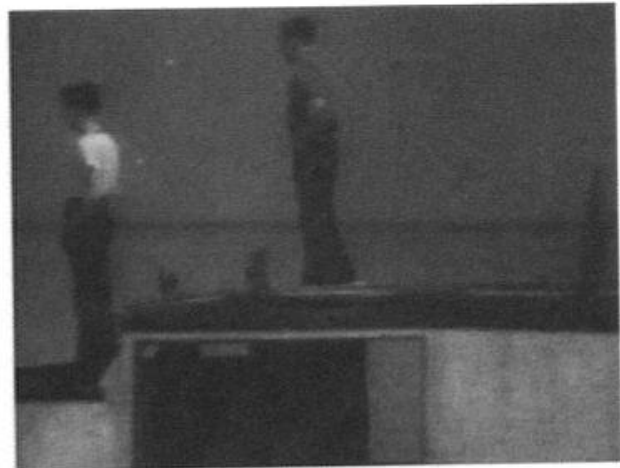

\section{Future for Fighters}

"Canada Communiqué \#10," NFB, 1944.

Demobilizing servicemen and their wives benefit from government assistance. Two beaming ex-sailors who will set up as a fishing partnership are shown meeting the government grant committee and trying out a new boat.

NARRATOR

Fishing was the trade of these seamen, and they want to get back into it 
as partners. Can they get a loan to set themselves up? Better than that. As the farmer gets his farm and the city worker buys a property, a fisherman gets $\$ 1200$ toward a boat and net and fishing gear. As partners these two receive a $\$ 2400$ grant as well as assistance in buying their own home.

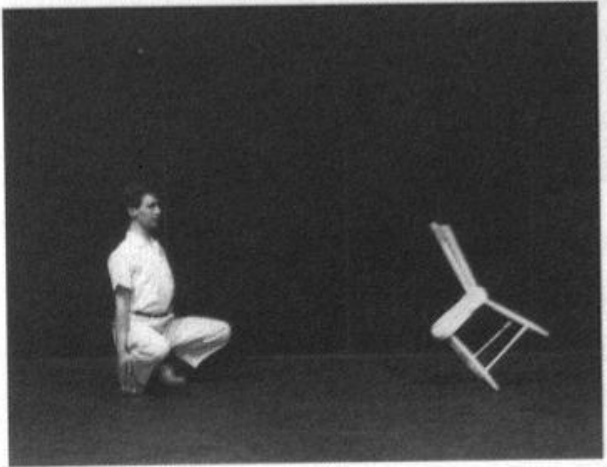

A Chairy Tale

Claude Jutra and

Norman McLaren,

NFB, 1957.

A pixillated relationship fable in which Claude and a non-gender specific chair struggle for an equal relationship. After a hot pursuit and courtship, the chair agrees to be sat on only if it's reciprocal.

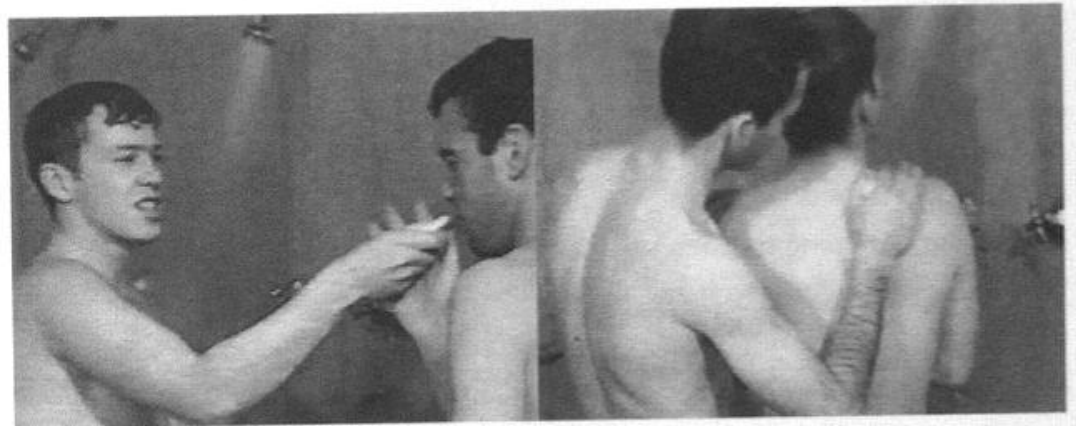

Winter Kept Us Warm, David Secter, 1965.

Winter Carnival at the University of Toronto: after various winter sports the residence gang head for the Hart House lockerroom. Much horseplay and towel snapping as they undress. Straight Peter, the Finnish drama major, expresses mock titillation at his buddy's bare chest. They all traipse self-consciously toward the showers (a historic rear view that constitutes English Canadian cinema's first male nudity?). Under the showers Peter jokingly tries to feed another buddy Doug the soap, but settles for peremptorily ordering him to scrub his back for him. Doug, who is discovering something ambiguous about his friendship, eagerly complies. 


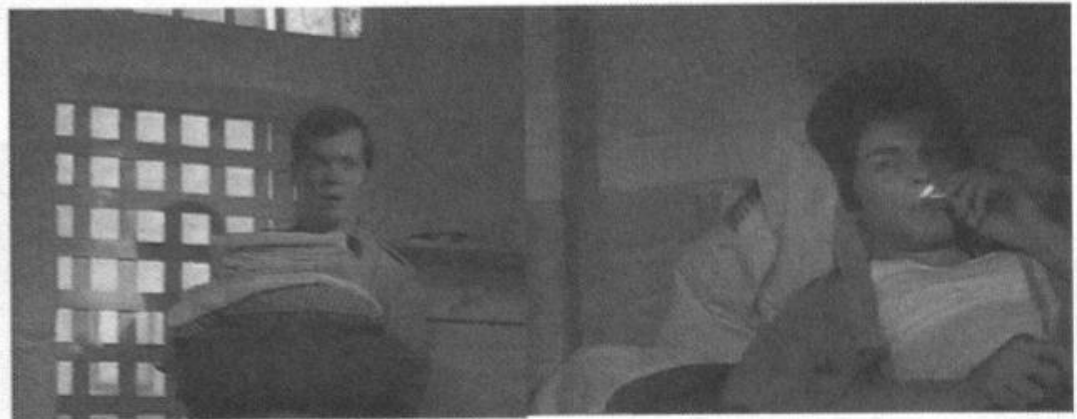

Fortune and Men's Eyes, Daryl Duke, 1971.

Naive Smitty, convicted pot smoker, sees his cell for the first time. His new roommate Rocky, lounging on his bottom bunk, welcomes him with a most intense stare.

GUARD

I'll give you the regulations later.

SMITTY

Yes sir.

GUARD

Trivers [Rocky], show him how to make his bunk, that is, if you ain't too busy. ROCKY

What's your problem kid, piles?

SMITTY

Is that my bunk?

ROCKY

You're not going to sleep with me, fishface.

Rocky blows out a match he has just lit as a rack focus closes in on his predatory stare at his new cellmate.

125 Rooms of Comfort, dir. Patrick Loubert, prod. Don Haig, 1975. Two scenes intercut: the hotel master of ceremonies introduces the "beautiful vivacious" new stripper to her rowdy and appreciative male audience. Meanwhile outside the hotel other drunken patrons discover Billie in drag and prevent him from getting away, shouting "Fucking faggot!" and "Hey we've got a faggot!" They beat him up, rip off his wig, kick him when he is down in the grungy alleyway, douse him with beer, and leave him for dead. 
Outrageous, Richard Benner, 1977.

A downtown hairdressing salon. Robin asks for time off from his uptight closety boss.

\section{ROBIN}

It's not tacky drag. I do real impressions. No records. My own voice. BOSS

And your own tits.

ROBIN

Tacky. All I need is Saturday afternoon off to shop and rehearse and you know.

BOSS

Listen, running a beauty salon is very serious. I mean, it's all in the image of the hairdresser. Those ladies don't come in here to have their hair done, they come in to have their egos boosted by men. If you lose that straight image, you lose the clients. Who wants to be felt up by faggots?

ROBIN

I can think of two people in this room who'd love it.

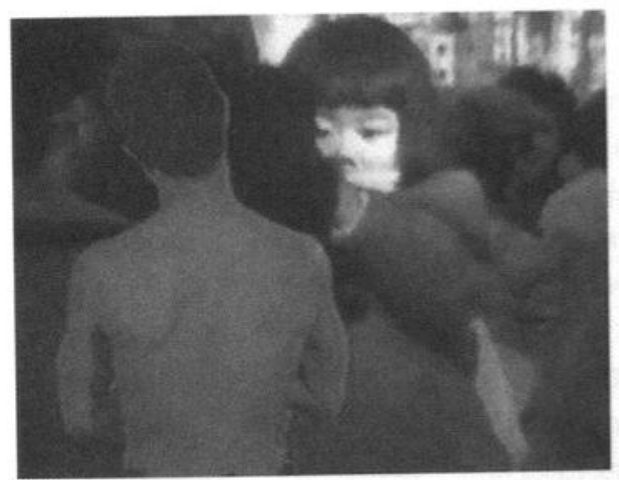

Chinese Characters Richard Fung, 1986.

Rear view of Chinese man, caressing his nude torso, keyed in against shots of passersby in Toronto's Chinatown.

\section{VOICEOVER}

I was brought up in working class, middle-class white small town Ontario, and I really reflect a lot of that, and I know it. But I think being Chinese I've had to open my eyes to a lot of other things. I'm trying to get rid of all my stereotypes of people. Just because we're non-white doesn't mean that we're not stereotypical either, that we don't have racist attitudes. 


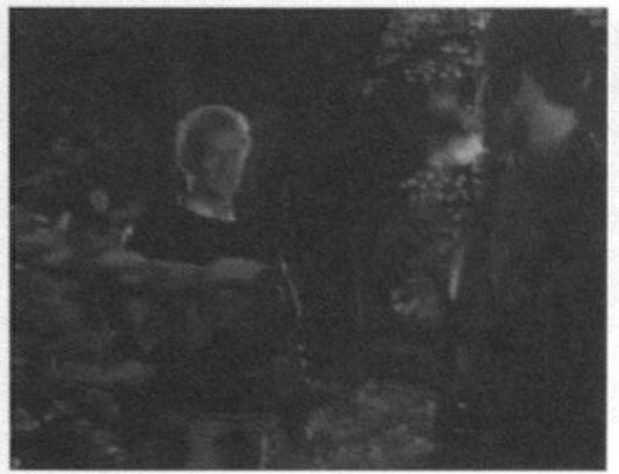

\section{The Making of Monsters} John Greyson, 1990.

A wood near Toronto. Two film actors head home after a day on the set, one calling the other's attention to a man who has just passed and cruised him.

ACTOR A

Oh I didn't notice.

ACTOR B

He noticed you.

ACTOR A

Are you into park sex?

ACTOR B singing, to the tune of Weill's "Surabaya Johnny"

I have always kept my sex in the bedroom,

Parks and tearooms are foreign to me,

I have never had the need for adventures,

What's the problem with monogamy?

There's a truth that we ought to remember, The best sex always takes the most work.

I am always looking for a loyal lover,

All I get are promiscuous jerks. 


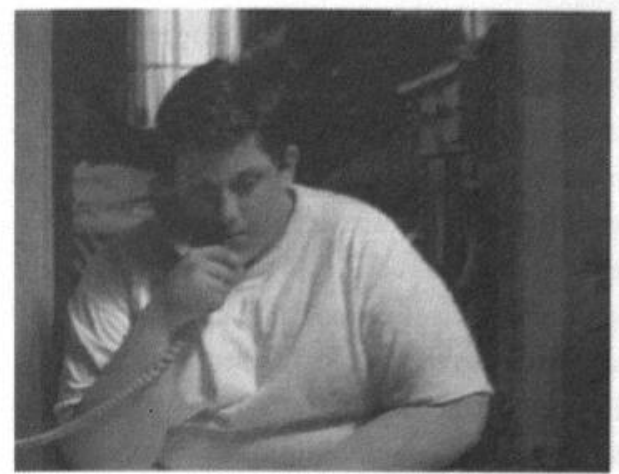

The Hanging Garden Thom Fitzgerald, 1997.

Obese queer teenage Willy broods in bed the morning after a special encounter with his redhaired buddy and then pads over to the phone.

WILLY

Is Fletcher there?

FLETCHER

What?

WILLY

It's me, Willy.

FLETCHER

I know. Whaddya want?

WILLY

Can you come over today?

FLETCHER

No. (pause)

WILLY

Tonight?

FLETCHER

I don't want to come over. I don't want your mother calling my mother. And I don't want to talk about it. I gotta go to school right now. Look, Willy. I don't want to talk about it, OK? 
ike Fletcher, we may not want to talk about it, but there's been an awful lot of talk going on all the same. The rich repertory of imagery that these glimpses can only hint at acquires when thus isolated a coherence as a corpus. A teleology seems to crystallize, the emergence from the subtext, if not to the surface, then to the margins of the surface, and then to those recent mitigated triumphs at the Genies, like Forbidden Love, Le Confessionnal, and Lilies. This surfacing has been explicit in the quantum proliferation of lesbian and gay voices in film and video over the last fifteen years, most dramatically extending to the NFB catalogues of the nineties, the guilty conscience of generations of liberal culturecrats in denial.

When I call this repertory an alternative canon, another canon is implied, the official canon or family of canons that has currency in our syllabi and on our postage stamps, for which the alternative canon serves as corrective, antidote, salon des refusés. One would think that the canonizers would be as hard put to avoid the queer invasion of the nineties as Genie voters have been. But no. The traditional definition of the "national" in terms of gender and cultural hegemonies (white male heterosexual authors from Cronenberg to Arcand as the arbiters of national cinemas and identities)—or "leaving gender out of it," as Michael Dorland has put it. ${ }^{8}$ The practice of "leaving" of women's cinemas and even more marginal cinemas for "non-national" categorization has hardly shifted. And the frantic rush to enshrine Egoyan and Cronenberg as termpaper topics and course stuffers beyond all other contenders has been pointedly symptomatic of a desperate avoidance of acknowledging the shifting demographics and proliferating diversity of Canadian cinemas. Note the presence of both Toronto straight male directors, with an unrivalled three films each, on Take One's recent "top twenty" list, a masterpiece of hysterical revisionism, backlash tokenism and Toronto-centricity. ${ }^{9}$ As if we hadn't already been tortured enough by previous polls, lists, listings and anthology selections.

Another case in point: Geoff Pevere's and Greig Dymond's Mondo Canuck: A Canadian Pop Culture Odyssey. ${ }^{10}$ This canon is at least different from Take One's in that it is an adolescent suburban variant of the straight white male downtown Toronto chauvinism and has a healthy taste for trash. This is not a cheap dig, for the silencing and invisibility of sexual diversity - and ethnic diversity - is as systematic as it is blatant in this survey of popular culture. Mondo is predicated on a conception of popular culture as mainstream and media-borne and "available across the country," a conception that automatically excludes not only minority popular culture but also all regional and local popular culture by definition. (Even given the Toronto framework of the book, are public manifestations that propel 
hundreds of thousands of celebrators annually through the streets like Caribana and Gay Pride, not popular culture, and why not?) Take for example, the book's endless blather about hockey and the total embargo on figure skating, with no entries for Toller Cranston. Forget about disco or Craig Russell or General Idea or Svend Robinson or Joe Average or Vancouver's TV AIDS "Doctor Peter." "1 A sanitized discussion of "Kids in the Hall" leaves out Scott Thompson's queer humour and public persona, ditto for Codco and the late Tommy Sexton; the book's movie repertory focuses on the usual suspects of Cronenberg and Egoyan, omits Greyson and LaBruce and purges Rozema of the L-word; a profile of k.d.lang stresses her vegetarianism over her lesbianism. The only redeeming moment is a legendary coming out excerpt from a DeGrassi Higb script, quoted approvingly but then undercut snidely by a recitation of the PC issues taken up by the series: "Abortion, AIDS, substance abuse, sexual orientation and harassment, getting laid, smoking and generally surviving adolescence," issues which the authors by and large decided elsewhere had nothing to do with Canadian popular culture.

In the face of such silencing and exclusion, the queer canon, with its resilient iconography of community formation, troubled relationships, unrequited passion, self-hatred, camp bravado, internal prejudice, martyrdom, and, yes, positive images, is both a therapeutic communal history and an indispensable political resource.

But something is wrong with this picture. I have been luring you along through a familiar discourse, the kind of diatribe about exclusion and stereotype and the demand for inclusion that have been the formula of identity/minority cultural politics in North America since 1965, around gender, race, ethnicity, and regional identity, as well as around sexuality. Such discourse, and the simultaneous construction of defensive countercultures, are necessary tactics for minority survival, nurturance and mobilization, granted. The prospering network of queer film and video festivals in every single regional centre in Canada is testimony enough to that. But these are tactics that Eve Sedgwick might call minoritizing, not only creating guilt and English Canadian colonialism, but also perpetuating the separation of ghetto and mainstream. ${ }^{12}$ They cement the place of marginality, denying through this schematic oppositionality a more universalizing model of sexuality, denying the complex circulation of desire and denial, attraction and repulsion, through which sexuality finds its social expression. They perpetuate "solitudes" of sexual and cinematic culture without regard for the border-crossings either of postmodernity or within the transhistorical libido as postulated by Freud. 
And indeed much theory and practice of minority representation has moved beyond the seventies corrective discourse of exclusion and inclusion. Here I might quote at some length the British black lesbian film and video maker Pratibha Parmar to explain the necessity of moving fluidly beyond the corrective measures of minority cultural practice:

I do not speak from a position of marginalization but more crucially from the resistance to that marginalization. As a filmmaker, it is important for me to reflect upon the process through which I constantly negotiate the borderlines between shifting territories... between the margin and the center...between inclusion and exclusion...between visibility and invisibility.... Instead of allowing our marginality to impose a silence on us, we are actively engaged in making videos and films that have begun to redefine and recast notions of "mainstream," "difference," and "otherness" [and I might add parenthetically "the popular"]. It is important to create and proclaim assertive and empowering images which question and unsettle the dominant discourses of representation of people who are not white, male, and heterosexual, but it is equally important to move beyond the merely oppositional.... [Recent audience responses to my work to the effect that, ] as an Asian lesbian filmmaker, my territory should be proscribed and limited to my very specific identities, and to my own communities...have reinforced my criticism of an essentialist identity politics as being divisive, exclusionary, and retrogressive. I would assert that our territories should be as broad as we choose.... It is important...that we are not constrained and contained by...fixed identity tags...that we do not get caught up in an essentialist bantustan that decrees that you do not cross boundaries of your experiences. Such prescriptive thinking can be both creatively and politically stultifying.... I reject the idea that $\mathrm{I}$ am forever relegated to the confines of an outsider looking in. ${ }^{13}$

Parmar spoke as a maker and practitioner. What are the implications of moving beyond corrective oppositionality, moving beyond the ghetto for us theorists, historians, critics, and teachers?

For one thing, we need to fundamentally rethink the discursive links between sexuality and national identity within our cinemas, for they often testify to the same contradictory mix of excess, disavowal and mystification that sexuality faces in our culture as a whole. A whole literature has grown since Fothergill's now infamous 1973 article, "Coward, Bully or 
Clown, the Dream Life of a Younger Brother," which rivals Laura Mulvey's 1975 "Visual Pleasure and Narrative Cinema" in the way it has bedeviled all subsequent research in its field, everyone's favorite whipping-boy. ${ }^{14} \mathrm{At}$ least methodologically speaking, the encyclopedic Fothergill was far ahead of many younger scholars, listing dozens of films that few of us have seen since, and offering no shortage of interesting conclusions. His sampling, all fiction features, was derived from babyboomer subcultures of straight male middle-class resentment, coming of age in the late sixties and seventies, principally in the metropolitan centres, and fixating on the institution of auteur cinema. But this Canadian Kracauer's extrapolation from his genre findings to an imagined level of national psycho-cultural applicability, from Pete'n'Joey to Preston Manning, was stretching it. His leaps back and forth between cinematic themes of male heterosexual angst and collective psychic and politico-economic dependency may have suited the Anglo nationalist discourse of the post-Centennial era but had hardly any diagnostic value. Not that such leaps were not explicit in some of the films Fothergill cited, such as Paperback Hero and the 1975 feature flop 125 Rooms of Comfort (just included as part of my queer canon). But explicit assertions of national identity have more to do with individual sentiment than collective experience. And lest anyone doubt the heteronormativity of Fothergill's metaphoric equation of national identity with sexual dysfunction, or as he calls it "goofy sexual incompetence," allow me to quote from his contemporaneous review of 125 Rooms of Comfort, this fable of a once grand Southern Ontario hotel taken over by American greed. Fothergill refers to the mob queerbashing scene that is the climax of the film: "Is Billy's transvestism an image of the total 'feminisation' of the son and heir of the Canadian mansion, an expression of an unconscious desire to be raped $?^{\prime \prime 15}$ Whoa. Here he transposes a little too deftly the sexist myth of the woman who wants to be raped to the queer to wants to be bashed and in the same breath to the Canadian who wants to be colonized.

A counter-literature on masculinity in Canadian film has taken issue with Fothergill and his mentor Margaret Atwood, justly so on several scores (judging from Survival, Atwood's knowledge of Canadian fiction film was apparently limited to Goin' Down the Road and The Rowdyman). ${ }^{16}$ But for all its rigorous originality and feminist perspicacity, this literature seems to be equally content with heteronormative conceptions of masculinity, uncritically throwing around loaded terms like "emasculation" and otherwise implying a monolithic unitary conception of masculinity, and numbingly repeating a shopping-list litany of gender, race, class, culture and region that tactfully omits sexuality and orientation. Usefully offering 
detailed symptomatic analyses of specific films, rather than lists of films, this literature limits its corpus unaccountably to the heterocentric canon of straight male crisis-I Love a Man in Uniform, Perfectly Normal and their like. As if Winter Kept Us Warm, Montreal Main, Outrageous, Zero Patience, and The Hanging Garden and the rest of the alternative canon of gay male resilience, had nothing whatsoever to do with masculinity. Are we not men?, I am tempted to ask. The project of aligning this heterocentric cinema of male crisis with a monolithically framed conception of national identity formation, still seems to be fundamentally in play-whether based on logics of allegory, metaphor, metonymy, or clinical analysis - and all the challenges to Fothergill have not changed that basic problem.

In Quebec, where the masculinist subcultures of resentment have at least permeated an authentically popular narrative mythology, certified at the box office from Les deux femmes en or to Les Boys, Fothergill's method, properly qualified, might at least be more fruitful, but that's another, different story. In our postnational context of English Canada, is there really any way to generalize about collective cultures of sexuality except through artistic licence? The parodic faux-naif allegories of Joyce Wieland, or the self-conscious postmodern performance of John Greyson's videotape You Taste American, in which male strippers using giant cutout maple leaves as fig leaves and pasties do a lascivious fandance to the sound of Anne Murray's "Snowbird," call into question the assumptions of national identity rather than transmit them wholesale. Thus while Richard Dyer quite plausibly argues that the hustlers of sixties American fiction are searching for America, ${ }^{17}$ it will not solve anything for us to start claiming that Bruce LaBruce's hustlers are searching for Canada, for they are clearly not. So let's agree to call a moratorium on the national pronoun "we." Let's postpone the alignment of our rich mosaics of cinematic and sexual culture with imagined national libidinal constellations within the fragmented, multi-cultured, and centrifugal legal entity whose passports we hold. Let's bracket the national-sexual that has prematurely and problematically been the animus of Canadian film studies.

The project that I would like to propose then is not a queer alternative canon to replace the conventional canon of Toronto straight-male, middle-class, baby-boomer, art-movie angst that we have elevated into national status, as in Canadian National Exhibitionism-but of a canon queered. ${ }^{18}$ Let us then now take a second tour through imagery of masculinity in Canadian film history as a means of wondering what it might look like to see queerness not on the margins, but as a troubling centre and structuring absence, provoking a final reflection that will not provide 
answers but perhaps point to several areas where we can roll up our sleeves. The relevance of these transcribed excerpts may not be immediately clear, but will hopefully emerge in my subsequent discussion, and the pleasure of curiosity and excavation routinely experienced by marginal readers of any text will hopefully compensate for any initial perplexity.

\section{THE CANON QUEERED}

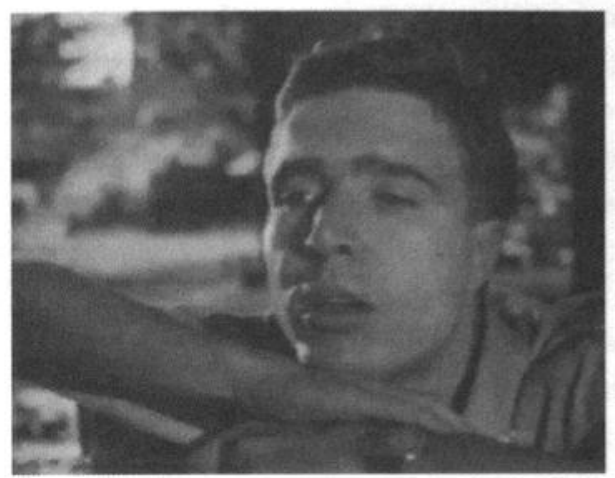

The Stratford Adventure Morten Parker, Gudrun Parker, Guy Glover, NFB, 1954.

A handsome young actor bicycles up to Alec Guinness as opening night in the big tent draws closer.

TIF

About that line, the one you suggested I change the reading of. Well, I followed your advice this morning.

ALEC

It was worse? I'm sorry, Tif, I've run out again [of cigarettes]. (they light up) Thank you.

TIF

Now it fell flat every runthrough. Guthrie didn't say anything but I know it did. Maybe it's this breath control he's always talking about.

ALEC, mentoringly.

Probably, partly. But also you're trying something new and-with something new you become what any actor becomes, so obsessed with the technical problem that you lose the spirit of the line. Give it a week and it'll sort itself out.

TIF

It takes time. We open on Monday.

ALEC

Yes, probably. But it's good to know what we're up against. What's that 
line of yours to Hastings, "It's a vile thing...", something?

TIF, in dreamy closeup, head tilted on his folded arms

"It's a vile thing to die my gracious lord when men are unprepared and look not for it."

ALEC

"And look not for it." Same problem really.

TIF

But is it? I mean l've been changing it because of the emphasis.

ALEC

Well, why not try taking it straight through? It drops at the end and you can't be heard because you've only got a cupful of air in your lungs. Can you do six lines of Shakespeare on one breath.

TIF, with acolyte's tone

It's a big order...

VOICE OFFSCREEN

Ready, Alec?

ALEC

Ready. I'm just about to consult my lecture notes. Coming to eat?

TIF

Yes I am.

ALEC

Pardon me while I climb into a heavy disguise.

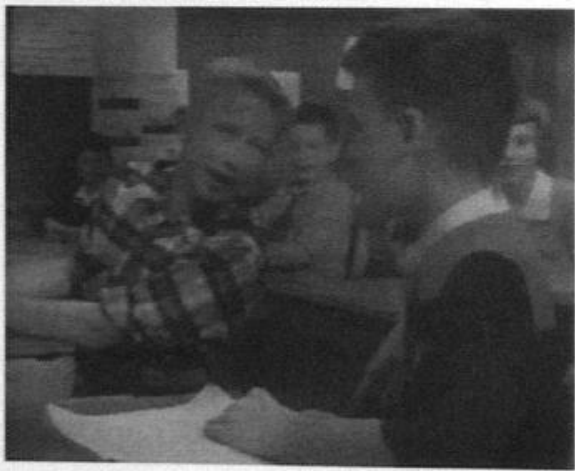

Being Different Julia Murphy, Gudrun

Parker, NFB, 1957.

A trigger film intended to spark discussion about non-conformity shows an elementary teacher trying to encourage nonconventional gender performance by reading 12 -year-old George's essay.

MISS BILLINGS

There's one composition I should like to read aloud. I'm going to call it "Discovery" because the person who wrote it and wrote it very nicely 
discovered a new interest this summer, a fascinating one and there's nothing more exciting in the world than discovering new things. The composition was written by George Laidlaw.

George grins sheepishly, fielding looks of admiration.

TOM, admiring classmate

George Shakespeare.

MISS BILLINGS

"This summer, my family went to a cottage on Green Lake, and that is where I met Dr. Robbins who lives right next door. He's not the kind of doctor we think of but he's a doctor of science. That is also where I met Steve Robbins whose father is Dr. Robbins. He's going to be a scientist too. Dr. Robbins spends every summer at the lake doing one thing. He catches butterflies. (Pupils laugh, Miss Billings gives a horn-rimmed castrating look.) He told us there are very many different butterflies around Green Lake and that is why he comes there. A week after we first met, Steve came over with two butterfly nets (titters) and asked if I would like to go over to the Nelson farm. That is about a mile away. He was looking for a special butterfly and he wanted me to help him. I said I would walk over with him, but I wasn't going to chase any butterflies. He said OK and it was a very nice walk to Nelsons'. And that was my first expedition with Steve. By the time summer was over I could hardly wait every afternoon to go out with Steve and catch butterflies. It was not only fun but it was very interesting (look of eye-rolling irony from male classmate). I discovered that butterflies are very interesting to know about. I wonder how many people..." (saved by the bell). Oh that's too bad. I thought I'd have time to read it all. There's a lot of interesting information in this composition. I'm going to put it on the bulletin board and you can read it yourselves later.

CLASSMATE, ironic

Boy, I can hardly wait.

ANOTHER CLASSMATE

Oh, I just love butterflies.

MISS BILLINGS

I'll return the rest of the compositions first thing in the morning. Class dismissed.

THIRD CLASSMATE

Hey George lend me your butterfly net sometime, eh?

FOURTH CLASSMATE

I played with dolls this summer, what did you do Larry? 
Sweet Substitute, Larry Kent, 1964.

T-shirted high school graduate Tom regales his buddy, lying on the other twin bed in his bedroom with a pillow between his legs, with fantasies of a transCanada joyride.

TOM

Here's what we gotta do when I get the car. Can hardly wait. Right across the country. Sure. Stuff all over the place, just begging for it. Oh, millions

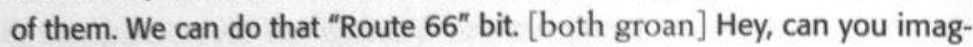
ine? I mean, can you imagine? I can see it all now. Vroom, wham, wham. Calgary first stop. Yahoo, yippee. That old ride'em cowboy shoot'em up stuff, eh? Hey, hey, I've got something we can really show'em how to ride. Vroom. The prairies! Saskatchewan, where the land is as flat as a billiard table. The broads! Think of all those big, milk-fed farmers' daughters (hits his friend for emphasis). Just dying for a little company. Hey, I betcha we could really accompany them, eh? And then. Wham! The big town. The party girls (Indian whooping by both). Can you see us now? There, with two, one for each arm, with four others, all around you, you know, oh boy. Oh those Montreal girls, really! Hey maybe we could stash a couple in the trunk and bring'em back in the car. Oh what a trip! I can't bear to think about it (pummels him with pillow). Oh boy.

BUDDY

Come on lets get out there.

TOM

Where?

BUDDY

Well, to get some broads, of course.

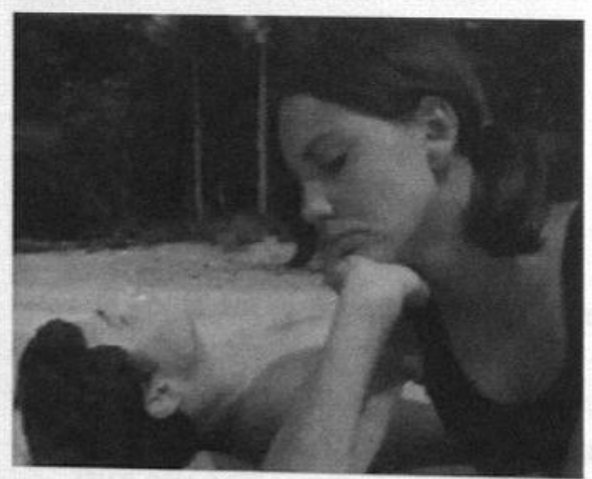

Phoebe

George Kaczender, NFB, 1964.

A beach near Montréal. Teenaged Phoebe and her beau sunbathing, but she's tortured by the need to tell him she's pregnant. 


\section{PAUL}

Whose idea was it to call you Phoebe?

\section{PHOEBE}

My godfather. He's got these funny ideas. He's an artist. Lives in Italy. My parents say he's crazy.

PAUL

Did you ever meet him?

PHOEBE

No.

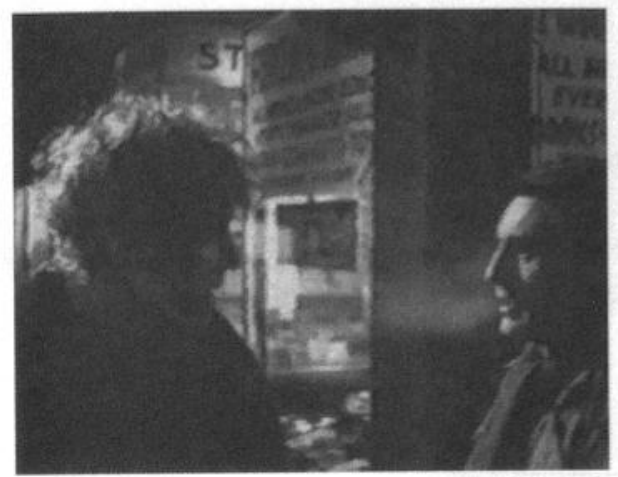

The Ernie Game

Don Owen, NFB, 1967.

Alienated youth Ernie has met suspicious-looking Derek May in an encounter with a drunken damsel in distress in a snowy Montréal parking lot.

ERNIE

What did you say when she stopped you? Were you sympathetic towards her?

DEREK

Maybe. I don't know. You run into a lot of situations like that.

ERNIE

Yeah. I followed her out of the bar for some reason.

DEREK

You probably thought you could help her.

ERNIE

Yeah. How did you know that?

DEREK

I could tell as soon as I got a look at you.

Now on Ste-Catherine Street, they look into each other's eyes.

\section{ERNIE}

Yeah, you really know things. 


\section{DEREK}

Maybe. Where you going now?

ERNIE

I dunno.

DEREK

You want to go to bed with me?

ERNIE

No.

DEREK

Are you sure?

ERNIE

Where do you come from?

DEREK

California. My hotel's this way. I'll see you around.

\section{ERNIE}

Yes, no, listen, I don't feel like being alone right now. Can I come up to your hotel room for a drink?

DEREK

$\mathrm{OK}$, sure, sure.

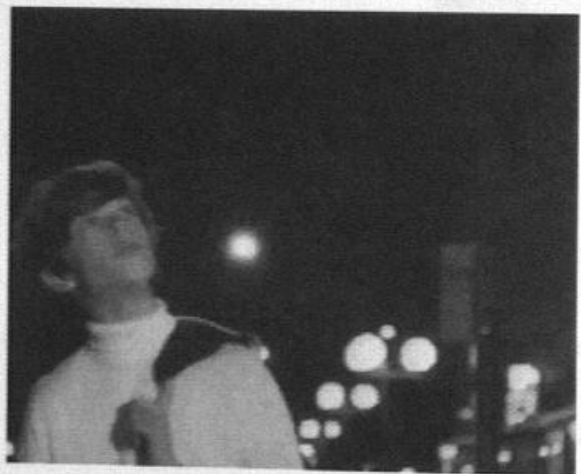

Don't Let the Angels Fall dir. George Kaczender, scen. Timothy Findley, NFB, 1968.

Charmion King, playing anxious Westmount mother Myrna, enters the bedroom of her sullen, hooky-playing 13-year old son Guy, to try to shake him out of it.

\section{MYRNA}

I'm telling you this because you're a human being and because you're going to suffer whether you like the idea of it or not. It's there, it's reality. And you must learn to deal with it. I just want you to survive. You understand? (shakes head) Whatever's wrong with you or wrong for you, whether it's sex (meaningful interrogatory pause), or school, or an 
enemy, or your father, or me. I want you to be able to conquer it. And get the hell on with life. Listen to me. Go back to school. Take from it what you can. But the world that you're going to be living in isn't going to be the same as our world, I know that. But whatever kind of world it is you're going to have to live there or die.

Cut to Place Jacques-Cartier, night, upbeat music. Eyes gleaming, jacket jauntily over shoulder, Guy strides confidently towards the camera across the deserted intersection, at first a high angle long shot then a low angle medium close view of the rebel.

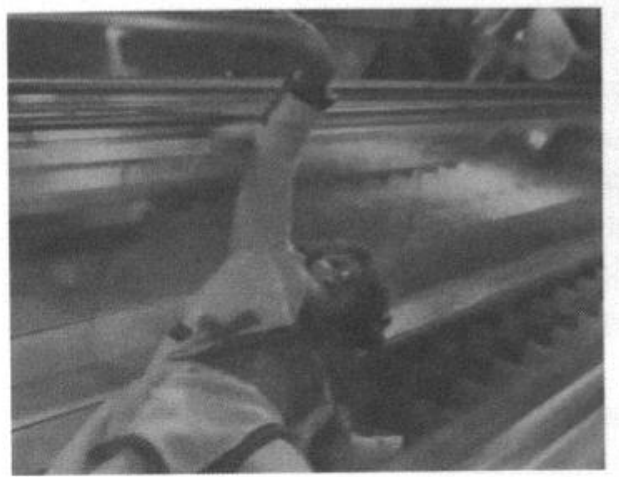

\section{The Silent Partner Daryl Duke, 1978.}

An Eaton Centre shootout after a botched holdup by sadistic arch-criminal Christopher Plummer, in elegant Chanel-suited drag, mascara and wig. Foiled by quivering hetero couple Elliott Gould and Susannah York, and shot by the bank guard, Plummer tries to escape up the down escalator, but collapses as he nears the top. His blood soaked corpse, arms and legs akimbo but tasteful pumps intact, is carried inexorably back down to the scene of spectacular transgression. 


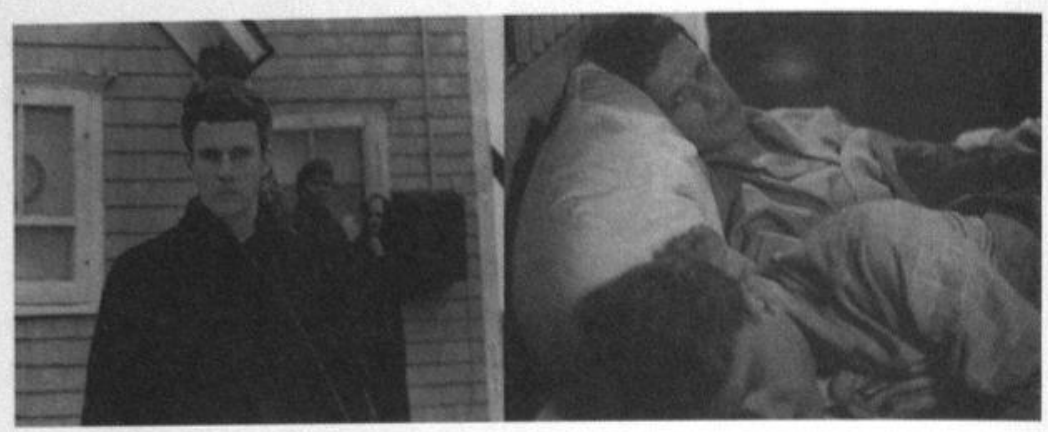

The Bay Boy, Daniel Petrie,

\section{4.}

After a hard night on the floor after having resisted the gestures and confidences of Father Chaisson (Mathieu Carrière) in their double bed, teenaged jock/altar boy Donald (Kiefer Sutherland) cuts short his visit to his Acadian friends, ostensibly for a rescheduled hockey game.

FR. CHAISSON, handing him a small wrapped package

Got room in a pocket for this?

DONALD

Thanks, Father.

FR. CHAISSON

Donald, I hope you win.

DONALD

Huh? Oh, thanks.

FR. CHAISSON

Donald?

DONALD

Yes, Father?

FR. CHAISSON

I hope you'll pray for me.

DONALD

Yes, Father.

Donald's truck leaves as the tormented staring face of the priest is held in closeup. Later, Donald opens the parcel, a missal, as his bus passes over a bridge, then tosses it into the river below, where the tainted object splashes and disappears. 


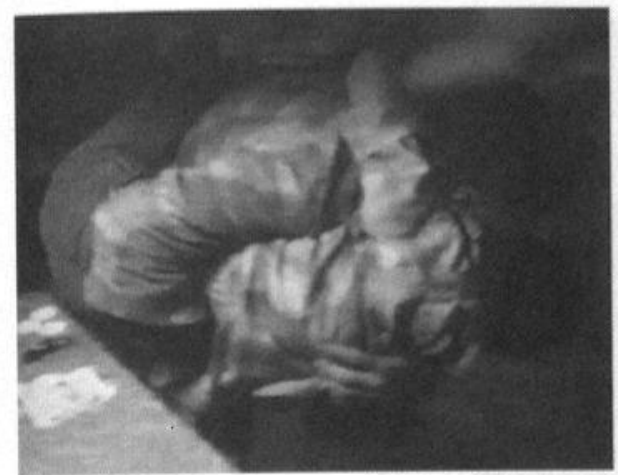

\section{Cowboys Don't Cry}

Anne Wheeler, 1988.

Studious, sensitive boy, really named Shane, confronts his alcoholic rodeorider dad, really named Josh, in their Alberta farm kitchen.

\section{SHANE}

You're finished. You'll never be champion again. You're a joke.

They exchange slaps, and start fighting, but the slender teenager is no match for his father, who ends up overwhelming him.

Go ahead kill me, just like you killed Mom.

JOSH

My God is that what you really think? You've been wanting to say that for a long time, haven't you?

SHANE

I guess.

Josh gets up, packs his things, throws his son some money on the table, and exits.

SHANE, smashing a beer can through the window, sobbing Dad I hate you. 


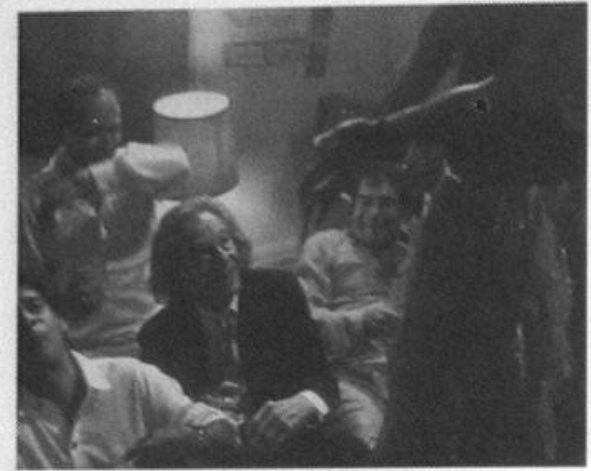

Sam and Me

Deepa Mehta, 1991.

A Toronto stag party of immigrant young men, of Indian and other Asian origins, plus their elderly Jewish guest, Sam, all well advanced on wine and song. A Hindi film song plays, and Baldev, a tall muscular man, dances into the room in nautch girl drag, pointed toes first, lip syncing, winking and shimmying his buddies into a frenzy. He eventually dances with the old man, lifts him up in an ecstatic Pieta-like pose. Abrupt cut to another sex scene, this time hetero, middle-aged and dysfunctional.

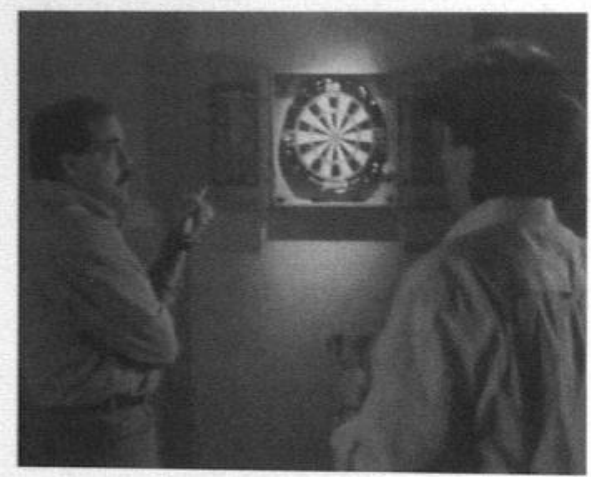

The Myth of the Male Orgasm John Hamilton, 1993.

Two twenty-something yuppy bachelors playing darts.

JIM

Maybe I'm homosexual.

TIM

What?

$\mathrm{JIM}$

No, I'm serious. I was walking down the street the other day right behind this long-haired babe, right? She was really goodlooking from behind, so you know, I pick up the pace and I get up to her. When I look at her face, it's a guy. 
TIM

And this qualifies you as having homosexual tendencies?

JIM

Well it got me worrying about it.

TIM

Now I'm sure, you're an idiot. Homosexual! How did you ever get a job teaching?

JIM

You never think about it?

TIM

I for one am perfectly comfortable with my manhood.

JIM

OK, well forget about sex. I mean you've never looked at some guy and found him attractive, even in some remote way?

TIM

Wouldn't know an attractive guy if he ran me over.

JIM

Yeah, right. Unless he'd just picked up a woman you were trying to meet. TIM

Nope. I'd just put that down to poor taste on her part. Sorry, Jim, no confused thoughts up here. (points to his prematurely balding head)

SEAN, a third TYB, saving the day

Drinky-poos anyone, on me?

TIM

Yeah, I'm in. Jimmy here's working his way out of the closet and I'd rather not be alone with him while he does. I'll just change my shirt. Tim mock-effeminately flounces out. Jim hits a bull's eye. 


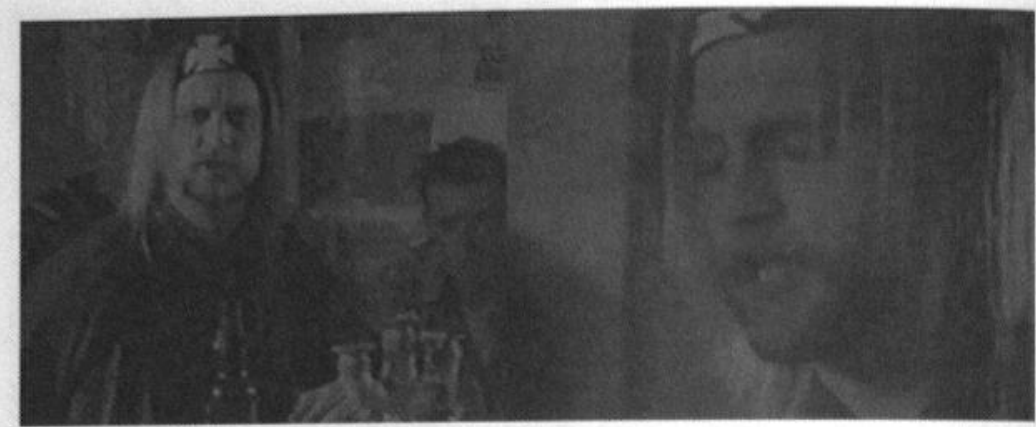

Hard Core Logo, Bruce McDonald, 1996.

An Edmonton breakfast on the last tour of a punk band. Drummer Pipefitter has discovered the diary of guitarist John, a sensitive stammerer. PIPEFITTER, reading in a mock stammer

"What the hell's happening to us?" Anyway-anyway, listen to this. "All week we went through these motions just holding our breath in case someone whispers a secret-" Oooh! "- too soft to hear. Well, I held my breath long enough. I heard the secret and I realized that I really came on this tour because I can be honest with these guys and nobody else." There's more. Wait. "I came back. When I'm at home I have to take these pills." No Shit. (Another band member throws something at him to warn him that John has come in behind him) Here's a pill-would you fuck off? "I have to lie to everyone. I lie to Celine, I lie to myself, and I lie to everyone else. I had to get up every day and tell this lie, every day, about being normal, and before the reunion came up, I was scared I'd wake up one day and believe that lie for the rest of my life. Makes me wonder what lies the other guys are believing." Is that hilarious or what? You guys aren't laughing. (sees John) Oh shit.

JOHN, stammering

Well that settles one thing. I never knew if you could read, read or not. PIPEFITTER

I'm sorry man. I'm sorry man. Look. Oh fuck.

BANDMEMBER, offscreen

You hurt his fucking feelings. You're so fucking stupid.

PIPEFITTER, laughing

You loved it. 
T he primary task involved then in deciphering this queer epic of normative masculinity on our screens, what the new Supreme Court Justice would call this "faggoty dressup party,"19 is its historicization. This entails firstly a broadening and deepening of the corpus, obviously, not only in the sense of Fothergill-style listmaking, but also its rigorous contextualization. Secondly, let's reorder the thematic and generic terms of the filmic analysis that have been at the core of the literature around cinema, gender, and nation.

Our corpus needs to expand beyond the lazy conservative sampling of auteur feature films available on video, to be blown wide open to the prolific materiality of film cultures in Canada-now that we have 60 years of the NFB documentary and animation, forty years of experimental films, thirty years of federally funded independent features, and thirty years of artists' video behind us. Graduate students are not taking enough risks with our heritage of the abject and unreleased, the pretentious and well-intentioned and prize-winning, the misunderstood and censored. They are not indulging in the guilty pleasures of the whimsical and absurd, the lustful and exploitative, nor in the cinematic activisms and solidarities around causes that history is trying to make us forget or be ashamed of.

One preliminary pleasure for me in this job of queering the canon will be purely archeological. It is indeed a sweet substitute to excavate the unacknowledged role of queer networks, sensibilities and bodies in defining and interrogating, both synchronically and diachronically, the axis of masculinity in our cinematic legacies. Of course such an enterprise will contribute to both the minoritizing mission of the queer canon and the universalizing task of the canon queered. Either way, the basic research has not even begun. Scrape around with me in my spur-of-the-moment compilations for a moment.

Take Guy Glover: producer of approximately 290 NFB films over almost thirty-five years beginning in 1941. A bilingual Alberta-raised poet and critic, Glover is remembered as a witty party-thrower, Norman McLaren's open but discreet lover for all of that time and his survivor by only two years when he died in 1988, and above all as a producer passionately engaged with the ideas and images of his films. Though one of the most influential figures in Canadian film history, there is no entry for him in The Film Companion or the other standard English-language reference books. ${ }^{20} \mathrm{His}$ Stratford Adventure is not the only film to reflect his longstanding collaboration with the Board's cadre of pre-Studio D women filmmakers, including Gudrun Parker, scriptwriter for both Stratford and Being Different. Nor is it 
Glover's only title to suggest discreet subterfuge, wordplay and open secrets, the search for alternative masculinity and even the possibility of sexual transgression: Illegal Abortion, Of Sport and Men, The Inner Man, The Searcbing Man, The Monastery, A Musician in the Family, Opera Scbool, etc., etc. My delectation of such titles is of course the ultimate in warped Canadian camp, but a thematic analysis of the films also reveals Glover's commitment to intercultural exchange, nonconformity, progressive causes, and especially the performing arts. Glover, a ballet and theatre lover, had been hired by Grierson apparently because he wanted his boy friend, and another Canadian wouldn't hurt, though by the end of the War Glover had already made his mark as a producer, he had also been typecast by the boss as a performing arts specialist. The performing arts had always provided a safe nurturing space for the expression of subterranean homoerotic affiliation and desire both in themselves and through their cinematic and photographic interpretations, and looking at Canada film history from this point of view opens up a whole new field of enquiry. Look at the punctilious tenors and willowy young men in wire-rim glasses and suits who wander through Glover's arts films as accompanists and you will know about both non-macho models of masculinity and gender performativity before their time.

One of Glover's rare public utterances is a 1967 article, "How to Make a Canadian Film,"an ironic scolding of the new waves of the late sixties, as uttered by an old guard producer of the tradition of quality. Among his Swiftian barbs at the indiscipline, modernist editing structures and narcissism of the baby-boomer Fellinis around him, is a note about themes: "Youth in revolt is a perfect subject-area. Post-teens in revolt is perfect for a post-teens director. Departures from mental and sexual norms (so-called) are especially desirable." ${ }^{21}$ In that parenthetical "so-called," there seems to be just a tiny hint, two years before the decriminalization of sodomy in Canada, of the relativity of those norms, the only crack in this public armour of mentorial disdain where the private queer elder glints indulgently through.

Or if you prefer, look again at The Stratford Adventure, that Oscar-nominated compendium of pre-Candid Eye fifties taste. The scene I selected was singled out for criticism by at least one nervous heterosexual critic, ${ }_{1}^{22}$ and Tif, the dreamy eyed young actor who wants to share cigarettes and technique with Alec Guinness, is now better known as gay Canadian novelist Timothy Findley. This is not Findley's only appearance in Canadian film, having made other later contributions to against-the-grain inscriptions of masculinity in his own right as scriptwriter, and not only to one of the queerest (in several senses) films ever made in Canada, The Wars, an adaptation of 
his novel by another Stratford veteran Robin Phillips. I am referring to that archetypal film of the sixties Sexual Revolution, George Kaczender's still unrehabilitated Don't Let the Angels Fall, a veritable encyclopedia of masculinities in crisis (and femininities as calming centres and erotic others). Was Findley in conspiracy with actress Charmion King about her epochal inflection of the word "sex", when she's trying to decipher her son's revolt? So what if son Guy would only have discovered American tourists on Place Jacques-Cartier the year after Expo, and hadn't yet discovered the Main's pinball parlours as his friend Johnny would do in Montreal Main six years later. For me Findley invented the character that encapsuled the torment of growing up male-hetero or homo-in an entire generation of Canadian film. The boy, whether in catatonic torment on his bed or breezily experiencing the emancipation of the nocturnal streets, reminds me of how Kobena Mercer and Isaac Julien have looked closely at male black pop music of the same period. There they rediscovered, in a way similar to ours, the voices of softness, diversity and "'struggle' around the very meanings of masculinity," a rehabilitation of the popular culture of the past and a challenge to unquestioning stereotypes of black machismo. ${ }^{23}$

But I would like to move beyond these archeological cruises with queer ancestors subverting the mainstream, and forestall any inference that I am ascribing anachronistic and rigid seventies gay liberation labels to such fluid pre-seventies images. As compelling as my rereading of Angels is, it would let us off the hook to see the diversity of masculine models and the anxiety over masculinity itself as the work of a closet fifth column.

Since both the Glover and Findley digs have led us to the late sixties, let's think about this period as a whole, which I have already stenographed as the Sexual Revolution, and which my compilations confirm as crucial for concentrated further research. The period, which we could delimit as the two decades on either side of the birth of the Canadian Filmmakers Distribution Centre in 1968, the period between I Was a Ninety Pound Weakling and Lonely Boy at one end and Outrageous and Silent Partner at the other. The Sexual Revolution is crucial because it is perhaps the most understudied and misunderstood of several key nodal points in the convulsive history of the modernization of our cinemas, the eruption of the social and cultural infrastructures of the sex-gender system, the crumbling of the continuum of homosociality as busily as Canadian cinemas were enshrining it.

Our cinemas' obsessive preoccupation with sexuality was distinctive in many ways but was fundamentally hardly different from that of most modernizing, young or new wave cinemas that emerged since the War, 
both Western and postcolonial, both state-subsidized and independent, flourishing or floundering within fragile domestic markets and the international art cinema marketplace. Whether celebrating, exploiting or anguishing over sex, our cinemas never stopped speaking it and increasingly showing it. Since the fifties our cinemas in all their formats and genres erratically followed, challenged, denied or otherwise reflected the radical upheavals and cyclical lulls in the sex-gender system, namely: the proliferating commoditization of sexuality and leisure; the wholesale movement of women into the workplace and the subsequent emergence of feminism as a political movement; the pill and the redefinition of gender paradigms, from the myths and realities of marriage and family to the phenomenon that Barbara Ehrenreich characterized as the male flight from commitment ${ }_{i}{ }^{24}$ the emergence of modern nationalist movements, whether the Quiet Revolution or "Centennial nationalism" in English Canada, and their interface with the babyboomer youth revolt, its politicization and commercialization. The emergence from silence of sexual marginality, not only homosexuality but also sexual reform constituencies around reproductive rights and prostitution, has been just one aspect of this clamour around our coming of age into sexual modernity: the breakdown of erotophobic censorship allowed the cinema to be the primary register of this coming of age, but it was also its precondition.

It is against this backdrop that this period's cinemas of male crisis must be viewed. And, as I have already intimated, we need to make use of Eve Sedgwick's concept of male homosociality. ${ }^{25}$ For these cinemas, overwhelmingly male-authored, are overwhelmingly not so much about relations of men and women - though images of women may often be at the centre of their iconography - but about relations of men and men, about the patriarchy. From male love narratives to male conflict narratives, the apparatus of sexual difference is embodied not in its literal visualization, but in the entire range of narrative, mythological dynamics of same-sex sociality.

An inventory of these dynamics expressed in the cinemas of the Sexual Revolution-documentary, nontheatrical, experimental, fictionmight look like this:

Homosocial bonding narratives: the ambiguities and vulnerabilities within same-sex institutions, networks and rituals; friendship cloaked in infantilization and combat; the probing, timid or rash but irrepressible, of the homosocial continuum, its actual points of overlap and transition where the homosocial segues into the homoerotic, where corporal contact in the Hart House lockerroom or elsewhere becomes corporal intimacy becomes genital exposure becomes genital exchange, where talk becomes seeing 
becomes looking becomes doing, doing without acknowledgement becomes doing with disclaimer, becomes doing with saying. All of these points are on an axis where the boundary between going too far and going just far enough is ambiguous, oscillating back and forth according to personal, generational, and cultural determinations. Poor George Laidlaw and the makers of Being Different didn't know or pretended not to know where the boundary existed or even that it existed.

Narratives of the traffic in women, the exchange of women: the classic fracturing of the static heterosexual couple binary through the figure of the triangle; men sharing women, ownership, rivalry, jealousy or conflict over women, or as Sedgwick would put it, men desiring men through women. In the scene in Sweet Substitute, sex itself in not the source of the teenagers' ecstatic frenzy but their shared anticipation of its tandem enactment with all those nameless broads.

Iconographies of the male body: its display, intensification, eroticization and disavowal; the laments of wounded masculinity, the body's tortures, humiliations, stupors, terrors, secretions and depletions. I was tempted to include The Terry Fox Story in my compilation, the closest thing we had to Que Viva Mexico until Kissed, but how can you excerpt from an epic of masculinist necrophilia that is so uninterrupted?

Spatial iconographies: beyond the safe sanctuary of suburbia, the fifties refuge of the nuclear family and heterosexual monogamy, the camera's rediscovery and exploration of urban danger zones, the forbidden underground of red lights, Place Jacques-Cartier, the Main, Skid Row, waterfronts, and the Yonge Street strip joints and beverage rooms of Winter Kept Us Warm and Goin' Down the Road; the snowy urban oases accommodating the shivering male ballet that Shebib quoted (stole?) from Secter; homosocial institutions with their no-exit recesses and zones of the forbidden, from Newfoundland orphanages to the Quebec fortress prison that accommodated both Fortune and Men's Eyes and Lilies.

Violence narratives: eruptions of sexual and homophobic assault, queerbashing, victimization, survival and resistance, battered sons, suicide rockers, dead queers.

Stories of male-male socialization: mentorship, parenting, pedagogy, coming of age ; guilty priests, drunk fathers, treacherous comrades, rebel sons; all the displaced erotic energies that animate the reproduction of male culture and the patriarchy.

Discourses of the Anglo discovery of ethnic and other alterities: their inevitable incorporation into the above narrative dynamics from rivalry to eroticization. 
Sedgwick offers a further precision about the culture of homosociality, the way its homo-hetero definitional dichotomy structures ways of feeling, thinking, and representing. Sedgwick has outlined a "long crisis of modern sexual definition" of hetero vs homo, in terms of "the centrality of the nominally marginal, conceptually intractable set of definitional issues to the important knowledges and understandings of twentieth-century Western culture as a whole," in particular of "the potent incoherences of homo/heterosexual definition [that have left] no space in the culture exempt. ${ }^{126}$ This is a sweeping claim, but given the utterly predictable rhythm of disclaimer tropes throughout English Canadian fictions, especially since the Sexual Revolution when the censor allowed them to be explicit, it is not hard to see this definitional stress at their heart. This is how to make sense of Being Different of course, that NFB remake of Tea and Sympatby and proto-feminist challenge to monolithic machismo, but also of the dozens of erratic jokes that come out of nowhere but everywhere, the ones in The Mytb of the Male Orgasm, for example, and perhaps most extreme, of the bodies of dead queers that litter 125 Rooms of Comfort and so many other sets (fewer in English Canada than in Montréal or Hollywood, granted).

Canonical auteurism is also illuminated by this perspective, as well: the listed voices of the Sexual Revolution period like Owen, Shebib and Cronenberg, can all be seen in terms of the pattern of definitional anxiety-Ive quoted the jokey but serious disclaimer scene from The Ermie Game - as can their successors Egoyan, McDonald, Maddin, L'Ecuyer, Wellington, Williamson and Virgo, all poets of troubled homosociality and the "queer other." Hard Core Logo has been recognized as one of several unabashed male love stories to have emerged in the nineties from the Toronto milieu-though punk rock is a less suspect performing art than Glover's opera and McLaren's ballet. The band member who transgresses the strict codes of homosociality - by keeping a diary!—is humiliated in the scene I've quoted, one of the film's many kneejerk differentiation or disclaimer scenes. In the works coming out of the Toronto school in particular, the pattern seems especially exacerbated-and I mean School in the literal sense, as if Norman Jewison's Canadian Film Centre is providing special workshops in sexual definition. Curtis and his narrator buddy in Curtis's Charm talk more of penises and blowjobs than of the eponymous "charm," and are intercut with Maya Deren's archival footage of Haitian men dancing together, but only after the major disclaimer of "that fag stuff" is pronounced. Of course the most nuanced works from this cycle, such as McDonald's and Egoyan's, are self-conscious about the definitional crisis 
they enact, but milk the open vulnerabilities and ambiguities that result no less for all their hipness.

I have tried to suggest angles and directions for exploring this crisis, these issues, these incoherences and contradictions, which overdetermined the cinematic sexualities of the Sexual Revolution and have lingered for subsequent generations as well, in Canada as well as elsewhere. From this point of view, the explicit queer discourses falling into the autonomous alternative canon I elaborated at the outset must be related to this cinema of male crisis. They must be situated not as margins but as a troubling core that transforms the corpus around it, that queers it. To come back to Heath's injunction, the queer core must not be seen as an "additional problem" in an understanding of cinemas, nations, masculinities, any more than sexual difference or ethnicity and race can be so seen. The crisis in homosociality, the definitional incoherence in our cinemas, cannot be seen either as "the dream life of a younger brother," nor as the fantasy of a crazy artist godfather who likes Greek mythology and lives abroad, cannot be seen as the narrative of dysfunction or emasculation. Instead, as Heath might have put it, this crisis and incoherence are points of contradiction and struggle that open up cinemas, nations, masculinities as systems of flux and multiplicity, of desire and pleasure, pain and politics.

\section{FILMS, VIDEOTAPES AND TELEVISION CITED}

(Titles are Canadian unless otherwise specified)

125 Rooms of Comfort (1975, dir. Patrick Loubert, prod. Don Haig)

The Bay Boy (1984, Daniel Petrie)

Being Different (1957, NFB, dir. Julia Murphy, scen. Gudrun Parker)

Les Boys (1997, Louis Saia)

The Bridegroom, the Actress, and the Pimp (1968, West Germany, Jean-Marie Straub, [Danielle Huillet])

A Chairy Tale (1957, NFB, Claude Jutra and Norman McLaren)

Chinese Characters (1986, video, Richard Fung).

Le Confessionnal (1995, Robert LePage)

Cowboys Don't Cry (1988, Anne Wheeler)

Curtis's Charm (1995, John L'Ecuyer)

Deux femmes en or (1970, Claude Fournier)

DeGrassi High (1980-1990, TV series, CBC)

Don't Let the Angels Fall (1968, NFB, dir. George Kaczender, scen. Timothy Findley)

The Ernie Game (1967, NFB, Don Owen)

Forbidden Love (1993, NFB, Lynne Fernie, Aerlyn Weissman)

Fortune and Men's Eyes (1971, Daryl Duke) 
Future for Fighters (1944, NFB, "Canada Communiqué \#10," Stuart Legg, James Beveridge)

Goin' Down the Rood (1970, Don Shebib)

The Hanging Garden (1997, Thom Fitzgerald)

Hard Core Logo (1996, Bruce McDonald)

Illegal Abortion (1966, NFB, Robin Spry)

I Love a Man in Uniform (1993, David Wellington)

The Inner Man (1964, NFB, Gordon Burwash, Mort Ransen)

I Was a Ninety Pound Weakling (1960, NFB, Wolf Koenig, Roman Kroitor)

Kissed (1996, Lynne Stopkewich)

Lilies (1996, John Greyson)

Lonely Boy (1961, NFB, Wolf Koenig, Roman Kroitor)

The Making of Monsters (1990, John Greyson)

The Monastery (1951, NFB, Roger Blais)

Montreal Main (1974, Frank Vitale)

A Musician in the Fomily (1953, NFB, Gudrun Parker)

The Myth of the Male Orgosm (1993, John Hamilton)

Of Sport and Men (1961, NFB, Hubert Aquin)

Opera School (1952, NFB, Gudrun Parker)

Outrageous (1977, Richard Benner)

Paperback Hero (1972, Peter Pearson)

Perfectly Normal (1990, Yves Simoneau)

Phoebe (1964, NFB, George Kaczender)

Qué Viva México! (1931-32, unfinished, S.M. Eisenstein; some footage used for Thunder Over Mexico, 1934, USA, Sol Lesser, and Time in the Sun, 1939, USA, Paul Burnfod and Marie Seton)

The Rowdyman (1972, Peter Carter)

Sam and Me (1991, Deepa Mehta)

The Searching Man (1961, NFB, Dennis Miller)

The Silent Partner (1978, Daryl Duke)

Soldiers All (1941, NFB, "Canada Carries On," Stuart Legg)

The Stratford Adventure (1954, NFB, dir. Morten Parker, scen., Gudrun Parker, prod. Guy
Glover)

Sweet Substitute (1964, Larry Kent)

Tabu (USA, 1931, F. W. Murnau)

Tea and Sympathy (USA, 1956, Vincente Minnelli)

The Terry Fox Story (1983, Ralph L Thomas)

The Wars (1983, Robin Phillips)

Winter Kept Us Warm (1965, David Secter)

You Taste American (1986, video, John Greyson)

Zero Patience (1993, John Greyson) 


\section{NOTES}

1. This text is a revision of the twentieth Martin Walsh Memorial Lecture. For their generous support and assistance, I am grateful to: colleague Dave Douglas and Queens University historian Paul Jackson for having guided me through the works of Larry Kent and certain "Canada Carries On" titles respectively; Renée Bourgault of the NFB for her help with the Glover filmography; Gudrun Parker for generously sharing her reminiscences of her NFB work and colleagues with me; the FCAR and Concordia University for generously funding this research; my research assistants Christine Harkness and Marisa Rossy, as well as Concordia film booker Danielle Carter; producer Don Haig for the cassette of 125 Rooms of Comfort; CJFS colleagues Bill Wees and Angela Stukator for their editorial assistance; and Janine Marchessault and the FSAC executive for the great honour of their invitation.

I have attempted to maintain the oral quality of the original lecture in the editing of this lecture for publication, although the transcriptions of excerpts and film stills can obviously not fully substitute for the two film compilations presented within the lecture.

2. FSAC's then-president Ron Burnett remembers the event somewhat differently, he confided after my lecture, namely that refractory FSAC members stayed away from Heath's presentation in droves, to his embarrassment before the international guest. This passive resistance version of the event is still consistent with my colonial reading.

3. Stephen Heath, "Questions of Property: Film and Nationhood," Ciné-Tracts, Vol. 1, No. 4 (Spring-Summer 1978), 8; rpt. Ron Burnett, ed., Explorations in Film Theory: Selected Essays From Ciné-Tracts (Bloomington and Indianapolis: Indiana University Press, 1991), 180-190.

4. Martin Walsh, "Political Formations in the Cinema of Jean-Marie Straub," Jump Cut, No 4 (1974); rpt. in Walsh, The Brechtian Aspect of Radical Cinema, edited by Keith M. Griffiths (London: BFI, 1981), 59.

5. Julia Lesage, "The Human Subject-You, He, or Me?" Screen, Vol. 16, No. 2 (Summer 1975), $77-82$.

6. See, for example, Chantal Nadeau, "La représentation de la femme comme autre: l'ambiguité du cinéma de Léa Pool pour une position féministe," Quebec Studies No. 17 (1994), 83-95; Jean Bruce, "Querying or 'Queering' the Nation: The Lesbian Postmodern and Canadian Women's Cinema," Conadian Journal of Film Studies, Vol. 5, No. 2 (Fall 1996), 35-50.

7. Historian Paul Jackson's work on this and other NFB films of this period will appear in his much anticipated doctoral thesis The Prejudice of Good Order: Homosexuality in the Canadian Military 1939-1945 (Queens University).

8. Future readers may need to be reminded that on the day before the lecture on which this text is based Michael Dorland had introduced and defended the latest monograph on national cinema at the 1998 FSAC conference-not inconsistent with my arguments about exclusion, incidentally-his So Close to the State/s: The Emergence of Canadian Feature Film Policy (Toronto: University of Toronto Press, 1998).

9. Wyndham Wise, "TAKE ONE's Top 20 Canadian Films of All Time," Take One, Vol. 6, No. 19 (Spring 1998), 18-27.

10. Geoff Pevere and Greig Dymond, Mondo Canuck: A Canadian Pop Culture Odyssey (Toronto: Prentice-Hall, 1996).

11. Dr. Peter Jepson-Young (d. 1992) appeared weekly in CBC-broadcast "AIDS Diaries," of which a posthumous compilation was nominated for an Oscar.

12. Eve Kosofsky Sedgwick, Epistemology of the Closet (Berkeley: University of California Press, 1990), see especially 1, 9, 44-48. 
13. Pratibha Parmar, "That Moment of Emergence," in John Greyson, Martha Gever and Parmar, eds., Queer Looks: Perspectives on Lesbian and Gay Film and Video (New York and London: Routledge, 1993), 5,7,9.

14. Robert Fothergill, "Coward, Bully or Clown: the Dream Life of a Younger Brother," Take One, Vol. 4, No. 3 (September 1973); rpt. Seth Feldman and Joyce Nelson, eds., Conodian Film Reader (Toronto: Peter Martin Associates, 1977), 234-249.

15. Robert Fothergill, "125 Rooms of Comfort," Cinema Canada, No. 18 (March-April 1975), 58.

16. Margaret Atwood, Survival: A Thematic Guide to Conodian Literature (Toronto: Anansi, 1972), 34.

17. Richard Dyer, Now You See It: Studies on Lesbian and Gay Film (New York and London: Routledge, 1990), 140.

18. I am vaguely aware that the "canon queered" is not my original concept and apologize to whomever I have stolen it from.

19. My June 1998 audience remembered that newly appointed Supreme Court Justice Earl Binnie had just got into trouble for using this slur in a public address, and later claimed that he was simply quoting it from Canada's "national newspaper" The Clobe and Mail. Eventually the phrase was indeed tracked down to a sixties television review and the Justice's curiously idiot-savant memory, if not social sensitivity, was vindicated.

20. This biographical data is based on interviews with Gudrun Parker on May 15, 1998 and with other NFB veterans over the years, as well as NFB data bases and the Glover entry in the Dictionnaire du cinéma québécois (1991).

21. Guy Glover, "How to Make a Canadian Film," in Andre Páquet, How to Moke or Not to Make a Conodian Film (Montréal: La cinémathèque canadienne, 1967), [unpaged], statement 3.

22. Rodney James, Film as a Notional Art: NFB of Canoda and the Film Board Idea (New York Arno Press, 1977), 166,168.

25. Kobena Mercer and Isaac Julien, "Black Masculinity and the Sexual Politics of Race," in Mercer, Welcome to the Jungle: New Positions in Black Cultural Studies (New York and London: Routledge, 1994), 141.

24. Barbara Ehrenreich, The Hearts of Men: American Dreams and the Flight from Commitment (Garden City, NY: Anchor, 1984).

25. Eie Kosolsky Sedgwick, Between Men: English Literoture and Male Homosocial Desire Niew York Columbia University Press, 1985), 1-4.

25. Sedguick, Epistemology, 1-2.

THOMAS WAUGH teaches at Concordia University, where he has also developed interdisciplinary curricula on the arts in Canada, on HIV/AIDS, and in queer studies. He edited "Show Us Life": Towards a History and Aestbetics of the Committed Documentary and is the author of Hard to Imagine: Gay Male Ersticisen in Pbotograpby and Film from their Beginnings to Stonewall and The Fruit Madbiae. Tenenty Years of Writing on Queer Cinema (forthcoming). His publicatioms on documentary, Canadian and Indian film and video, and sexual resresentation have appeared in many anthologies and periodicals. 